Journal of Digitovation and Information System

http://jdiis.de/index.php/jdiis

\title{
A Novel Integration of Social Capital, Emotional Attachment and Organizational Innovation
}

\author{
NoorUl Ain ${ }^{\mathrm{a}, *}$, Mehwish Waheed ${ }^{\mathrm{a}}$ \\ ${ }^{a}$ Department of Management, Università Ca' Foscari Venezia, S. Giobbe, 873, 30121, Italy
}

\begin{abstract}
Article Information

The social capital and attachment theory are employed to theoretically define the relationships between three social capital dimensions (trust, interaction density and cooperation), three-dimensional emotional attachment (affection, passion and connection) and organizational innovation - by considering the organizational climate as a potential moderator. This study proposes a) social capital and emotional attachment contribution to organizational innovation b) moderating role of organizational climate in the relationship between social capital, emotional attachment and organizational innovation. The suggestions conclude that keeping an account of employees' social capital and emotional attachment may help the organization to take an innovative position in the market.

Keywords

Social Capital, Emotional Attachment, Organization Innovation
\end{abstract}

\section{Introduction}

To many organizations, innovation is considered to be a sine qua non for the business success and proliferation in the recent capricious and complex environment (Panuwatwanich et al., 2008). Unfortunately, most of the innovations appear unsuccessful, often resulting in failure and frustration (Kitsios \& Grigoroudis, 2020; Maura Sheehan et al., 2013; Tidd et al., 1998). To manage innovations successfully, effective utilization of intangible resources at the inter-organizational level is particularly important because it is the place where innovation activities take place to achieve superior performance/returns (Panuwatwanich et al., 2008). Among intangible resources, organizational social capital has recently gained prominence, i.e. "the actual and potential resources embedded within, available through, and derived from the social networks within an organization that may be mobilized in order to increase the success rate for specific actions" (Nahapiet \& Ghoshal, 1998; Yu, 2013). It facilitates relationships between employees in order to share information, mobilize resources, exchange knowledge, cooperate and coordinate collective activities to create innovations (Adler \& Kwon, 2002; Sanchez-Famoso et al., 2014).

Despite having the potential for organisational innovation, social capital can prepare grounds for innovation failure (Chou, 2006; Dasgupta, 2000), if not handled properly. Without social capital, it is difficult for employees to exchange resources and perform new activities to create innovations. Thus, employees' reluctance to interact, cooperate and trust each other for exchanging knowledge within a formal group, may influence an organization's innovative outcomes, which subsequently affect its performance in the market. Alguezaui and Filieri (2010) suggested the relationship between social capital and innovation is still contentious, thus need more systematic research. Therefore, this study proposes how inter-organizational social capital stimulate organizational innovation. 
In addition, an emotional tie with the organization plays a vital role in building favourable or unfavourable perceptions towards an organization (Wu et al., 2008), which may subsequently influence the innovation process. Read et al. (2011) and Thomson et al. (2005) stated that an individual who develops an emotional attachment to a product with which he is in contact with a certain period of time, is more likely to invest in, committed to and willing to make sacrifices for that product. In a similar vein, employees' emotional attachment to an organization might predict their affectional bonding, commitment, involvement and connection to the organization. Prior studies reported well-established associations of consumers' emotional attachment to brands (Thomson et al., 2005), an eBook reader (Waheed et al., 2015), pets (Sable, 1995), and places (Jang et al., 2015), less has been portrayed in term of employees' emotional attachment to the organization and its effect on innovation outcomes. Therefore, this study proposes how employees' emotional attachment stimulate organizational innovation.

Furthermore, organizations require an appropriate internal environment that supports and encourages employees to work without hesitation (Wu et al., 2008) and build social relations. Thus, this study unearths the possible effect of organizational climate as a potential moderator in a relationship between social capital, emotional attachment, and innovation in an inter-organizational context. The following research questions are raised to understand the highlighted research gap.

i) How do social capital and employees' emotional attachment stimulate organizational innovation?

ii) Does organizational climate moderates the relationship between social capital, emotional and organizational innovation?

\section{Theoretical Background}

\subsection{Overview of Social capital theory and Attachment theory}

The theoretical groundings of social capital theory (SCT) stemmed from the community research (Jacobs, 1961), where it highlighted the notion that networks of strong interpersonal relationships that develop over a certain period of time, provide the basis for cooperation, trust and collective actions in city communities. The predominant use of social capital phenomenon is highlighted for career success (Seibert et al., 2001) and later adapted in various contexts from 1984 to 2014 see Figure 1.

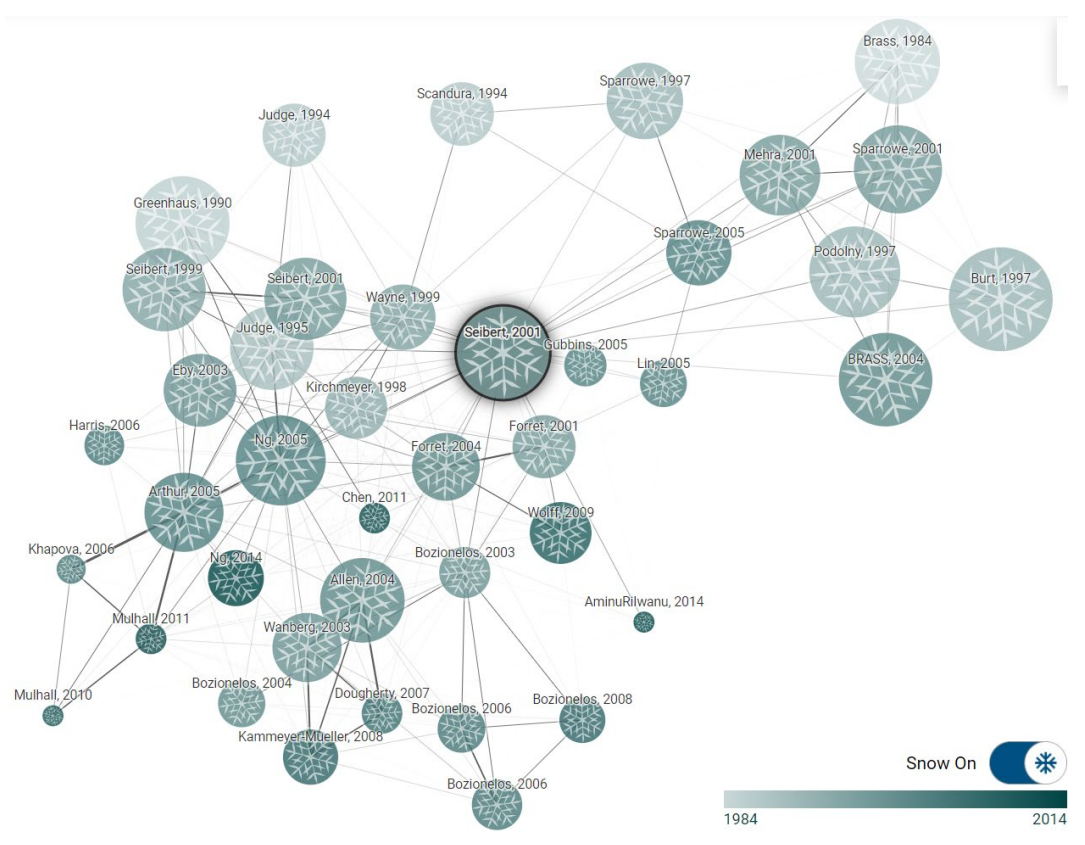

Figure 1: Social Capital Literature Map 
Thereafter, the concept has been applied to underscore the significance of social phenomena in many studies such as geographic regions (Putnam, 1993), young child development (Loury, 1977), nations (Quddus et al., 2000) and organizations (Baker, 1990). SCT emphasizes that interpersonal relationships promote rapport, trust, and goodwill, which in turn yield positive work-related outcomes (Maurer \& Ebers, 2006). Social capital provides access to a wide range of information resources, facilitates the combination and exchange of these resources, and propels innovation (Adler \& Kwon, 2002; Tsai \& Ghoshal, 1998). Onyx (2000) noted an association exists between social capital and innovation. Luthans and Youssef (2004) emphasized on organizations' internal resources - human, psychological and social capital - development enables them to gain a competitive advantage in the market. Organizations can retain advantages through complex and dynamic interrelationships. Yuanhui Li and Jin (2015) found that top managements' social capital effectively affects marketing strategies such as product development, marketing communication, pricing and distribution strategies. Additionally, scholars indicated that social capital can take different forms such as trust, interaction, norms, networks ties, shared codes and languages, shared narratives, identification (Jiang \& Liu, 2015; Nahapiet \& Ghoshal, 1998; Putnam, 1993)

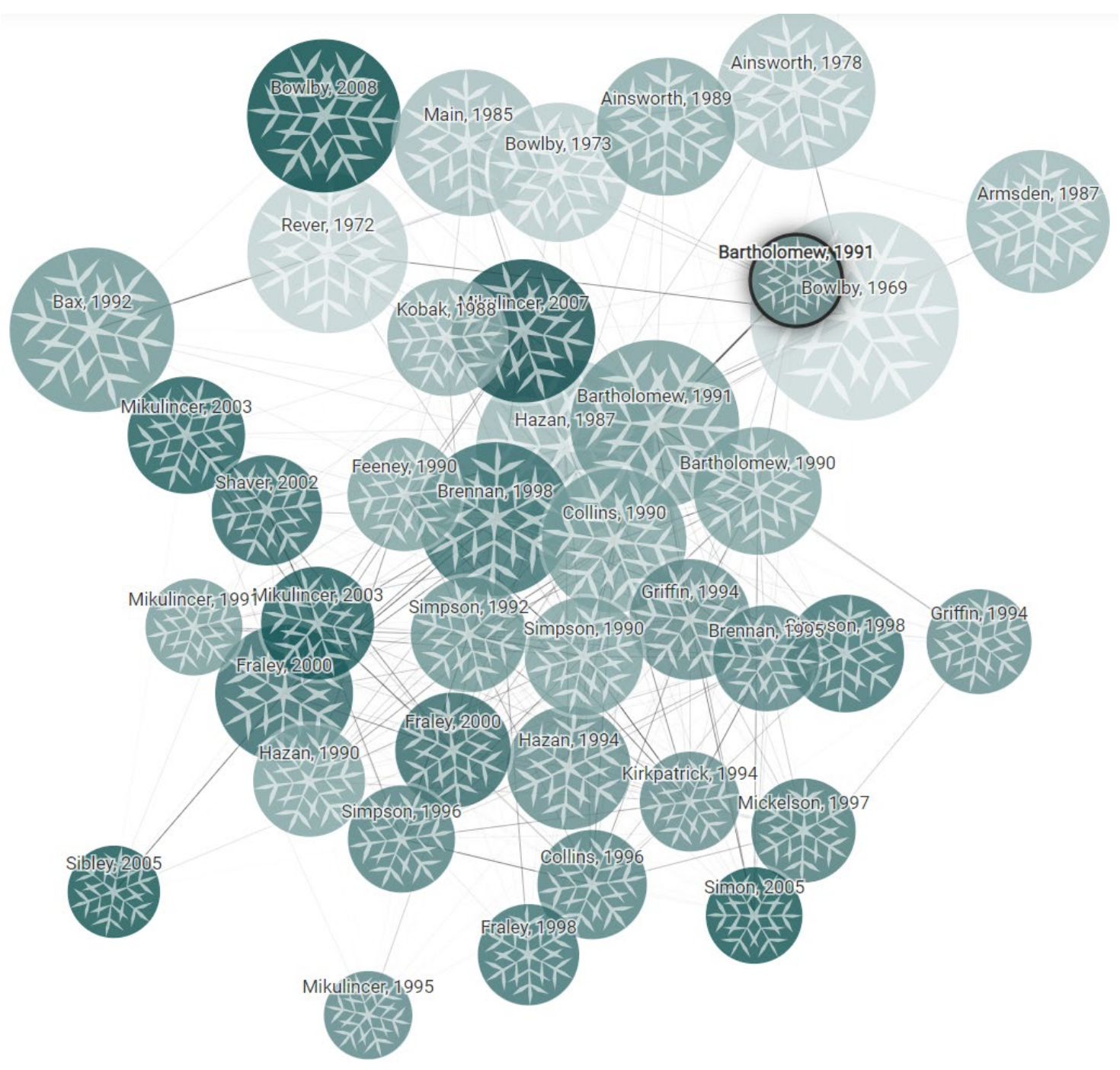

Figure 2: Attachment Theory Literature Map

On the other hand, attachment theory predicts the nature of an individual's interaction with a specific object (Bowlby, 1977). It deals with individuals' tendency to develop, dissolve and maintain affectionate ties with particular others (Bartholomew \& Horowitz, 1991; Hazan \& Shaver, 1994). A number of studies used the attachment theory in different contexts See Figure 2. McBride et al. 
(2021) explained the social, psychological impact of COVID-19 on people. Similarly, attachment style and temperament were studied and showed that the Italian population is severely affected during the COVID-19 pandemic (Moccia et al., 2020). Studies suggested individuals' emotional ties are most influential in an organizational context, as employees create favourable perceptions of the organization and perform better in the presence of strong emotional ties (Amabile \& Kramer, 2015; Wu et al., 2008). Strong emotions also provide motivation to act or not to act at certain points, and propel the innovation process (von Koskull et al., 2016). Further, emotional ties with a place, developed through experiences, significantly shape individuals' future behavioural intentions with respect to that place (Yuksel et al., 2010). Similarly, Jang et al. (2015) emphasized emotional attachment in building consumers' loyalty to green stores, maintaining their close relationship and commitment to that place. In marketing research, Whan Park et al. (2010) recently found emotional attachment as a significant determinant of actual brand purchase and a driver of brand loyalty. In the e-book reader context, Waheed et al. (2015) employed the attachment theory and innovation adoption model and suggested that the individuals' emotional attachment with paper books negatively influence the eBook reader adoption. Prior studies highlighted the importance of emotional attachment in different contexts. However, employees' emotional attachment to the organization and its association to innovation has not been addressed so far. Therefore, borrowing from the previous stream of work on social capital and emotional attachment, this study proposed a comprehensive framework to integrate the relationships among social capital, emotional attachment, organizational climate, and innovation.

\section{Research Framework and Hypotheses}

Following are the proposed hypotheses covering the relationship between social capital, emotional attachment, and innovation along with the moderating role of organizational climate.

\subsection{Social Capital and Organizational Innovation}

\subsubsection{Trust}

. Inferring from Rousseau et al. (1998) and Misztal (2013), this study referred to trust as 'an individual's willingness to accept others intended actions and behaviours appropriate from his/her point of view'. Trust is considered one of the crucial elements of social capital. Trust develops over time and facilitates greater openness to combine and exchange resources necessary for the value creation process. Organizations characterized by high levels of trust tend to innovate more (Landry et al., 2002), whereas low trust levels discourage innovation (Knack \& Keefer, 1997). Interpersonal trust is crucial for knowledge generation in highly ambiguous and uncertain settings and encourages knowledge sharing, communication of ideas and problem solving (Wu et al., 2008). Keeping these notions in view, this study argues that the more employees trust each other for exchanging knowledge without concealment and suspicion in intra-organizational settings, the more will be the organization's innovative outcomes. Thus, this study postulates;

Proposition1: Trust significantly affects organizational innovation.

\subsubsection{Interaction density}

In an organizational context, formal work-oriented relationships are the main reasons why employees interact with each other (Jiang \& Liu, 2015). Nahapiet and Ghoshal (1998) suggested that interaction as an important source to maintain and strengthen the social relationships among employees, which otherwise die out. Close interactions allow employees to know each other, create a common understanding of goals and task issues, share important information and gain access to each other's resources, which in turn foster the generation and implementation of new ideas (SanchezFamoso et al., 2014), which in turns influence innovation. Moreover, the organization brings its employees together to participate, supervise and coordinate assigned tasks and activities, particularly during the innovation process (Galbraith, 1973; Nahapiet \& Ghoshal, 1998). In such circumstances, 
employees' interaction is crucial as it provides them with the opportunity to share information and exchange knowledge to generate a pool of ideas for innovation development. In this regard, this study argues that the more employees interact with each other, the more they are open to each other. This generates an opportunity for employees to produce new creative ideas to develop innovation. Thus, this study postulates;

Proposition2: Interaction density significantly affects organizational innovation.

\subsubsection{Cooperation}

Jiang and Liu (2015) emphasized although different kinds of relationships may trigger employees' motivation in communication the cooperative working relationships are the most noticeable ones. It has been reported that cooperative relationships have the potential to predict the diverse behaviours of individuals during task accomplishment (Qin et al., 1995). To enhance the cooperative effectiveness, they are likely to build upon the common norm, fulfil the expectations of others and take on their own obligations (Jiang \& Liu, 2015). Kiratli et al. (2016) further suggested that creativity comes largely from individuals' collaborations when working collectively. In the context of this study, this study argues that the more employees cooperate with each other, the more they are able to understand each other, help each other, and identify ways together to solve problems during the value creation process and produce innovative outcomes. Thus, this study postulates.

Proposition3: Cooperation significantly affects organizational innovation.

\subsection{Emotional Attachment and Organizational Innovation}

Inferring from Thomson et al. (2005), this study referred to the emotional attachment as 'an emotion-laden target specific bond between an employee and an organization'. Emotional attachment is associated with stronger feelings of affection, passion, and connection (Read et al., 2011; Waheed et al., 2015). Emotional attachment predicts an individual's long-term association with a specific object (Thomson et al., 2005). Individuals can develop an emotional attachment to a variety of objects such as brands (Fedorikhin et al., 2008), groups (Paxton \& Moody, 2003) and celebrities (Giles \& Maltby, 2004). In a customer-brand relationship, customers' emotional attachment is underpinned by brand affection, love, and connection. These characteristics suggested that customers having strong emotional attachments are tend to be more committed, more involved through emotions, connected to the brand and stay in a long term relationship with that organization (Thomson et al., 2005). In the workplace context, emotional attachment binds employees to the organization, generating desiredriven persistence (Grisaffe \& Nguyen, 2011). Therefore, this study argues that employees who might have strong emotional attachment to the organization are more likely to psychologically invest in their work. The affectionate ties make them be highly motivated to invest effort into the tasks, dedicated by being passionately involved and committed to accomplish these tasks. This in turns lead them to generate organizationally valued novel ideas, which serve as building blocks for enhancing innovative outcomes such as generating new innovative products and services. Thus, this study postulates.

Proposition4: Affection significantly affects organizational innovation.

Proposition5: Passion significantly affects organizational innovation.

Proposition6: Connection significantly affects organizational innovation.

\subsection{The moderating role of Organizational Climate}

Inferring Prior studies indicated that an organization's climate is important to consider when individuals perform activities in a group and there is a need to overcome others' contrasting points of view (Kiratli et al., 2016). A favourable organizational climate may encourage employees to accept and trust others' viewpoints to achieve desired outcomes. Moreover, it is argued that a supportive organizational climate may facilitate employees to derive fruitful meaning from their interaction and devise desired results. Additionally, it may promote cooperative working relationships among 
employees. Furthermore, an encouraging climate might shape the employees' affectionate feelings towards their organization and their sense of association with the organization, which may motivate them to passionately engage and invest in innovation development activities. Keeping these notions in view, this study postulates;

Proposition 1a: The relationship between trust and organizational innovation is significantly moderated by organizational climate.

Proposition 2a: The relationship between interaction density and organizational innovation is significantly moderated by organizational climate.

Proposition 3a: The relationship between cooperation and organizational innovation is significantly moderated by organizational climate.

Proposition 4a: The relationship between affection and organizational innovation is significantly moderated by organizational climate.

Proposition 5a: The relationship between passion and organizational innovation is significantly moderated by organizational climate.

Proposition 6a: The relationship between connection and organizational innovation is significantly moderated by organizational climate.

\section{Research Methodology}

\section{Proposed Setting}

The proposed research setting is the consumer electronics manufacturers operating in Italy.

\section{Sample and data collection}

The targeted population for the study is the executives and managers, working in the R \& D department of chosen companies and a random sampling technique is used to select the respondents. The study will use the quantitative approach to validate the research framework by using the questionnaire survey for data collection.

\section{Discussion}

Implantation of social capital theory and attachment theory contributes towards building a novel theoretical framework to measure social capital, emotional attachment, and innovation relationships. This study provides the first attempt by integrating three social capital dimensions (trust, interaction density, and cooperation) and three-dimensional emotional attachment aspects (affection, passion, and connection) to determine innovation in an inter-organizational context. The possible upsurge of innovation products in the presence of organizational climate is also taken into account- as employees may rely on the organization's climate to develop appropriate behaviours to act in different situations. Implications are for practitioners and managers - while focusing on the strategies to promote social relationships - to manage the organizational intangible resources such as social capital is particularly important to consider because it is the place where innovation activities take place. Management can mobilize employees' resources and efforts to develop innovations, which subsequently lead the organization into good profits. Keeping account of employees' social capital and emotional attachment may help the organization to take an innovative position in the market. Organizations can create such an environment that encourages employees to communicate openly, share their vision, interact, cooperate and trust each other. Further, they can improve the organizational climate to nurture the emotional needs of employees. 


\section{References}

Adler, P. S., \& Kwon, S.-W. (2002). Social capital: Prospects for a new concept. Academy of management review, 27(1), 17-40. https://doi.org/10.5465/amr.2002.5922314

Alguezaui, S., \& Filieri, R. (2010). Investigating the role of social capital in innovation: sparse versus dense network. Journal of knowledge management, 14(6), 891-909. https://doi.org/10.1108/13673271011084925

Amabile, T. M., \& Kramer, S. J. (2015). Inner Work Life: Understanding the Subtext of Business Performance. IEEE Engineering Management Review, 43(1), 43-51. https://doi.org/10.1109/EMR.2015.7059374

Baker, W. E. (1990). Market Networks and Corporate Behavior. American Journal of Sociology, 96(3), 589-625. https://doi.org/10.1086/229573

Bartholomew, K., \& Horowitz, L. M. (1991). Attachment styles among young adults: a test of a four-category model. Journal of personality and social psychology, 61(2), 226. https://doi.org/10.3389/fpsyg.

Bowlby, J. (1977). The making and breaking of affectional bonds. II. Some principles of psychotherapy. The fiftieth Maudsley Lecture. The British Journal of Psychiatry, 130(5), 421-431. https://doi.org/10.1192/bjp.130.5.421

Chou, Y. K. (2006). Three simple models of social capital and economic growth. The Journal of Socio-Economics, 35(5), 889-912. https://doi.org/10.1016/j.socec.2005.11.053

Dasgupta, P. (2000). Trust as a commodity. Trust: Making and breaking cooperative relations, 4, 49-72. https://doi.org/10.1.1.25.5180

Fedorikhin, A., Park, C. W., \& Thomson, M. (2008). Beyond fit and attitude: The effect of emotional attachment on consumer responses to brand extensions. Journal of Consumer Psychology, 18(4), 281-291. https://doi.org/10.1016/j.jcps.2008.09.006

Giles, D. C., \& Maltby, J. (2004). The role of media figures in adolescent development: Relations between autonomy, attachment, and interest in celebrities. Personality and individual differences, 36(4), 813-822. https://doi.org/10.1016/S0191-8869(03)00154-5

Grisaffe, D. B., \& Nguyen, H. P. (2011). Antecedents of emotional attachment to brands. Journal of Business Research, 64(10), 1052-1059. https://doi.org/10.1016/j.jbusres.2010.11.002

Hazan, C., \& Shaver, P. R. (1994). Attachment as an organizational framework for research on close relationships. Psychological inquiry, 5(1), 1-22. https://doi.org/10.1207/s15327965pli0501_1

Jacobs, J. (1961). The death and life of great American cities. Vintage Books. https://doi.org/10.1108/14636680510611796

Jang, Y. J., Kim, W. G., \& Lee, H. Y. (2015). Coffee shop consumers' emotional attachment and loyalty to green stores: The moderating role of green consciousness. International Journal of Hospitality Management, 44, 146-156. https://doi.org/10.1016/j.ijhm.2014.10.001

Jiang, J. Y., \& Liu, C.-W. (2015). High performance work systems and organizational effectiveness: The mediating role of social capital. Human Resource Management Review, 25(1), 126-137. https://doi.org/10.1016/j.hrmr.2014.09.001

Kiratli, N., Rozemeijer, F., Hilken, T., de Ruyter, K., \& de Jong, A. (2016). Climate setting in sourcing teams: Developing a measurement scale for team creativity climate. Journal of Purchasing and Supply Management, 22(3), 196-204. https://doi.org/10.1016/j.pursup.2016.04.006

Kitsios, F. C., \& Grigoroudis, E. (2020). Evaluating service innovation and business performance in tourism: a multicriteria decision analysis approach. Management Decision, 58(11), 2429-2453. https://doi.org/10.1108/MD-09-2019-1326

Knack, S., \& Keefer, P. (1997). Does social capital have an economic payoff? A cross-country investigation. The Quarterly journal of economics, 112(4), 1251-1288. https://doi.org/10.1162/003355300555475

Landry, R., Amara, N., \& Lamari, M. (2002). Does social capital determine innovation? To what extent? 
Technological forecasting and social change, 69(7), 681-701. https://doi.org/10.1016/S0040$\underline{1625(01) 00170-6}$

Loury, G. (1977). A dynamic theory of racial income differences. In K. S. o. M. Northwestern University (Ed.), Women, minorities, and employment discrimination (Vol. 255, pp. 86-153). Center forMathematical Studies in Economics and Management Science, Evanston, IL.

Luthans, F., \& Youssef, C. M. (2004). Human, social, and now positive psychological capital management:: Investing in people for competitive advantage. Organizational dynamics, 33(2), 143-160. https://doi.org/10.1016/j.orgdyn.2004.01.003

Maura Sheehan, P., Ehlen, C., van der Klink, M., Roentgen, U., Curfs, E., \& Boshuizen, H. (2013). Knowledge productivity for sustainable innovation: social capital as HRD target. European Journal of Training and Development, 38(1/2), 54-74. https://doi.org/10.1108/EJTD-10-2013-0119

Maurer, I., \& Ebers, M. (2006). Dynamics of social capital and their performance implications: Lessons from biotechnology start-ups. Administrative Science Quarterly, 51(2), 262-292. https://doi.org/10.2189/asqu.51.2.262

McBride, O., Murphy, J., Shevlin, M., Gibson-Miller, J., Hartman, T. K., Hyland, P., Levita, L., Mason, L., Martinez, A. P., McKay, R., Stocks, T. V., Bennett, K. M., Vallières, F., Karatzias, T., Valiente, C., Vazquez, C., \& Bentall, R. P. (2021). Monitoring the psychological, social, and economic impact of the COVID-19 pandemic in the population: Context, design and conduct of the longitudinal COVID-19 psychological research consortium (C19PRC) study. International Journal of Methods in Psychiatric Research, 30(1), e1861. https://doi.org/10.1002/mpr.1861

Misztal, B. (2013). Trust in modern societies: The search for the bases of social order. Blackwell Publisher.

Moccia, L., Janiri, D., Pepe, M., Dattoli, L., Molinaro, M., De Martin, V., Chieffo, D., Janiri, L., Fiorillo, A., Sani, G., \& Di Nicola, M. (2020). Affective temperament, attachment style, and the psychological impact of the COVID-19 outbreak: an early report on the Italian general population. Brain, Behavior, and Immunity, 87, 75-79. https://doi.org/10.1016/j.bbi.2020.04.048

Nahapiet, J., \& Ghoshal, S. (1998). Social capital, intellectual capital, and the organizational advantage. Academy of management review, 23(2), 242-266. https://doi.org/10.5465/amr.1998.533225

Onyx, J. (2000). Social Capital, the Third Sector, and the Relative Importance of Strong and Weak Ties. th International Conference of ISTR, Dublin, https://doi.org/10.1017/S000397560000789X.

Panuwatwanich, K., Stewart, R. A., \& Mohamed, S. (2008). The role of climate for innovation in enhancing business performance: The case of design firms. Engineering, Construction and Architectural Management, 15(5), 407-422. https://doi.org/10.1108/09699980810902712

Paxton, P., \& Moody, J. (2003). Structure and sentiment: Explaining emotional attachment to group. Social Psychology Quarterly, 34-47. https://doi.org/10.2307/3090139

Putnam, R. D. (1993). The prosperous community. The american prospect, 4(13), 35-42.

Qin, Z., Johnson, D. W., \& Johnson, R. T. (1995). Cooperative versus competitive efforts and problem solving. Review of educational Research, 65(2), 129-143. https://doi.org/10.3102/00346543065002129

Quddus, M., Goldsby, M., \& Farooque, M. (2000). Trust: The Social Virtues and the Creation of Prosperity-A Review Article. Eastern Economic Journal, 26(1), 87-98. http://www.jstor.org/stable/40325970

Read, W., Robertson, N., \& McQuilken, L. (2011). A novel romance: the technology acceptance model with emotional attachment. Australasian Marketing Journal (AMJ), 19(4), 223-229. https://doi.org/10.1016/j.ausmj.2011.07.004

Rousseau, D. M., Sitkin, S. B., Burt, R. S., \& Camerer, C. (1998). Not so different after all: A cross-discipline view of trust. Academy of management review, 23(3), 393-404. https://doi.org/10.5465/AMR.1998.926617

Sable, P. (1995). Pets, attachment, and well-being across the life cycle. Social work, 40(3), 334-341. https://doi.org/10.1093/sw/40.3.334

Sanchez-Famoso, V., Maseda, A., \& Iturralde, T. (2014). The role of internal social capital in organisational 
innovation. An empirical study of family firms. European Management Journal, 32(6), 950-962. https://doi.org/10.1016/j.emj.2014.04.006

Seibert, S. E., Kraimer, M. L., \& Liden, R. C. (2001). A social capital theory of career success. Academy of management journal, 44(2), 219-237. https://doi.org/10.5465/3069452

Thomson, M., MacInnis, D. J., \& Park, C. W. (2005). The ties that bind: Measuring the strength of consumers' emotional attachments to brands. Journal of consumer psychology, 15(1), 77-91. https://doi.org/10.1207/s15327663jep1501 10

Tidd, J., Bessant, J., Pavitt, K., \& Wiley, J. (1998). Managing innovation: integrating technological, market and organizational change. In.

Tsai, W., \& Ghoshal, S. (1998). Social capital and value creation: The role of intrafirm networks. Academy of management Journal, 41(4), 464-476. https://doi.org/10.5465/257085

von Koskull, C., Strandvik, T., \& Tronvoll, B. (2016). Emotional strategizing in service innovation. Management Decision, 54(2), 270-287. https://doi.org/10.1108/MD-06-2014-0339

Waheed, M., Kaur, K., Ain, N., \& Sanni, S. A. (2015). Emotional attachment and multidimensional self-efficacy: extension of innovation diffusion theory in the context of eBook reader. Behaviour \& Information Technology, 34(12), 1147-1159. https://doi.org/10.1080/0144929X.2015.1004648

Whan Park, C., MacInnis, D. J., Priester, J., Eisingerich, A. B., \& Iacobucci, D. (2010). Brand attachment and brand attitude strength: Conceptual and empirical differentiation of two critical brand equity drivers. Journal of marketing, 74(6), 1-17. https://doi.org/10.1509/jmkg.74.6.1

Wu, W. Y., Chang, M. L., \& Chen, C. W. (2008). Promoting innovation through the accumulation of intellectual capital, social capital, and entrepreneurial orientation. $R \& d$ Management, 38(3), 265-277. https://doi.org/10.1111/1467-9914.00120

Yu, S.-H. (2013). Social capital, absorptive capability, and firm innovation. Technological Forecasting and Social Change, 80(7), 1261-1270. https://doi.org/10.1016/j.techfore.2012.12.005

Yuanhui Li, P. J. F., Professor, \& Jin, C.-H. (2015). The moderating effect of social capital and cosmopolitanism on marketing capabilities: A comparison of Chinese and Korean companies. Chinese Management Studies, 9(3), 441-466. https://doi.org/10.1108/CMS-04-2015-0071

Yuksel, A., Yuksel, F., \& Bilim, Y. (2010). Destination attachment: Effects on customer satisfaction and cognitive, affective and conative loyalty. Tourism Management, 31(2), 274-284.

https://doi.org/10.1016/j.tourman.2009.03.007 